\title{
Passenger Transport Disutilities in The US: An analysis since 1990s
}

\author{
Helcio Raymundo ${ }^{[0000-0003-4411-0466]}$ and João Gilberto M. dos Reis ${ }^{[0000-0001-6409-2299]}$ \\ Paulista University, Postgraduate Programme in Production Engineering \\ Dr. Bacelar, 1212, 04026-002 - São Paulo, São Paulo, Brazil \\ helcioruluol.com.br, betomendesreis@msn.com
}

\begin{abstract}
Even providing the means for human displacements, passenger transport causes disadvantages that can be called disutilities, such as time and money spending, insecurity and discomfort, and, negative impacts on communities. From the National Transportation Statistics, it is possible to measure passenger transport disutilities and reaches some conclusions that can help planning and public policies of the country. The results show that Americans are wasting more time and spending more money on their cars since the 1990s. Insecurity related to traffic in all modes of transportation has decreased significantly, and the discomfort in automobiles may have experienced an increase due to improvements in the infrastructure. America is lowering its per capita emissions of local gases, but there is insufficient data for conclusions regarding the greenhouse gases.
\end{abstract}

Keywords: Passenger Transport, Disutilities, Mobility, The USA.

\section{Introduction}

Despite supplying the means for people's displacement, passenger transport causes losses, inconveniences, and disadvantages that can be called disutilities. Passenger transport disutilities imposed on the passengers are time and money spending, insecurity and discomfort, and, on the society, negative impacts on communities. High levels of service imply low levels of disutility and vice-versa, and passenger transport problems are not evident by the occurrence of disutilities, but rather by its manifestation in undesirable levels [1].

This principle seems to have never been utterly present in driving the destiny of passenger transport in the world, and in the United States [1], otherwise perhaps the automobile might not have had been hegemonic, dividing its tasks with collective modes of transportation in a more equitable way, thus reducing the disutilities of passenger transportation in the country. The automobile is the preferred mode of travel for most Americans. Passenger transport in the country has always been based on it and the public transportation, although essential, plays a secondary role, and it has had a small market share [2]. These circumstances have permeated passenger transport industry (including governmental agencies) and have been shaping the offi- 
cial statistics, as, for example, the National Transportation Statistics, prepared by the Bureau of Transportation Statistics annually since 1970 [3].

Thus, considering that the National Transportation Statistics 2018 is one of the most comprehensive compendiums on transport and transit of the USA, it is possible to have in only one publication most of the elements that allow the country to evaluate past actions and anchor its future planning and the development of public policies [4].

Therefore, this paper aims to establish an overview of passenger transport disutilities in the USA from this source [4], adequately compiled, applying a specific and proper methodology to take measurements and corresponding analysis developed by the authors [5]. The authors conducted a similar study regarding the conditions of the Brazilian urban areas in the cities with more than 60 thousand inhabitants, representing about $60 \%$ of the population of the country, reaching satisfactory results [6].

\section{Material and Methods}

\subsection{Analysis of the National Transportation Statistics 2018}

Tab. 1 shows how to assess passenger transport disutilities.

Table 1. Disutilities Measurements (Source: Adapt [5,7,8])

\begin{tabular}{|c|c|}
\hline Disutility & Methodological Main Characteristics \\
\hline Time & $\begin{array}{l}\text { Complete journey time (timed or estimated), origin to destination, } \\
\text { regarding time spent }\end{array}$ \\
\hline Cost & $\begin{array}{l}\text { All expenses and trips cost should be included (cost per passenger): } \\
\text { (i) passengers' expenses with vehicles; (ii) fares, and (iii) non- } \\
\text { explicit cost of time }\end{array}$ \\
\hline Insecurity & $\begin{array}{l}\text { All passengers may suffer traffic accidents, which may result in } \\
\text { unsafe conditions. Typical accident rates can be adopted, weighted } \\
\text { by the number of inhabitants }\end{array}$ \\
\hline Discomfort & $\begin{array}{l}\text { Discomfort is limited not only to physical aspects but also of the } \\
\text { psychological side (privacy/freedom) in (i) public transport termi- } \\
\text { nals, stations, stops, and (ii) vehicles }\end{array}$ \\
\hline Negative & (i) consumption of areas devoted to infrastructure, and (ii) envi- \\
\hline Impacts on & ronmental impacts, this last one classified in noise pollution and \\
\hline Communities & $\begin{array}{l}\text { pollution caused by gases, liquids, and solids, that reach the air, } \\
\text { water and soil, measured by costs per passenger of noise pollution, } \\
\text { greenhouse gases emissions (GGE) }\left(\mathrm{CO}_{2}\right) \text { and local gases emissions }\end{array}$ \\
\hline
\end{tabular}

Time. Three sets of data and information could help to understand the disutility time:

- Annual Person-Hours of Highway Traffic Delay per Auto Commuter - "the extra time spent during the year traveling at congested speeds rather than free-flow speeds in the peak periods" $[4,9]$;

- Travel Time Index - "the ratio of travel time in the peak period to travel time at free-flow conditions" [4,9]; and 
- Annual Roadway Congestion Index (RCI) - "a measure of vehicle travel density on major roadways in an urban area during the peak period" [4].

Despite the similarities between these indicators, all of them highlight a considerable and worrying time spending growth. Undoubtedly, people using cars in the USA are spending more time every year, from 18 hours in 1982 to 42 in 2006, almost 2.3 twice more. Also, despite the small relief experienced in recent years as of 2008, the indicators have returned to their previous levels as in 2011 (Fig. 1).

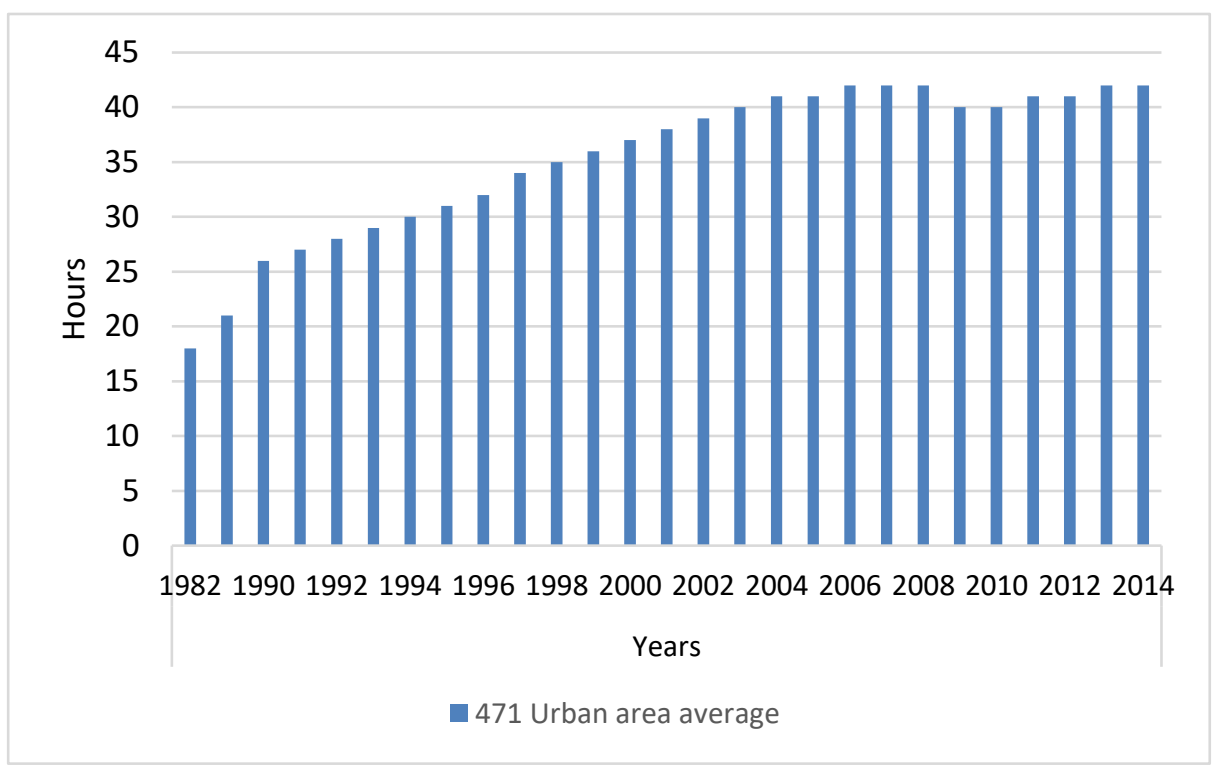

Fig. 1. Annual Person-Hours of Highway Traffic Delay per Auto Commuter (Source: [4])

Cost. People are spending more money using their cars in the USA since 1998, considering:

- Annual Highway Congestion Cost per peak Auto Commuter - "cost of wasted time and fuel associated with congestion" $[4,10]$; and

- Expenditures per Capita - the result of the indicator "Personal Expenditures by Category - millions of current dollars" [4], chained into 2014 by the US Inflation Calculator [11] and divided by the correspondent population [12].

The per capita expenditures, from a level of almost US\$1,800 in 1960, reached US\$ 3,300 in 1985 and went to US\$ 3,900 in 2005 (2.2 twice more about 1960), maintaining an average at a level of US\$ 3,600 during 2011 to 2014 (Fig. 2). 


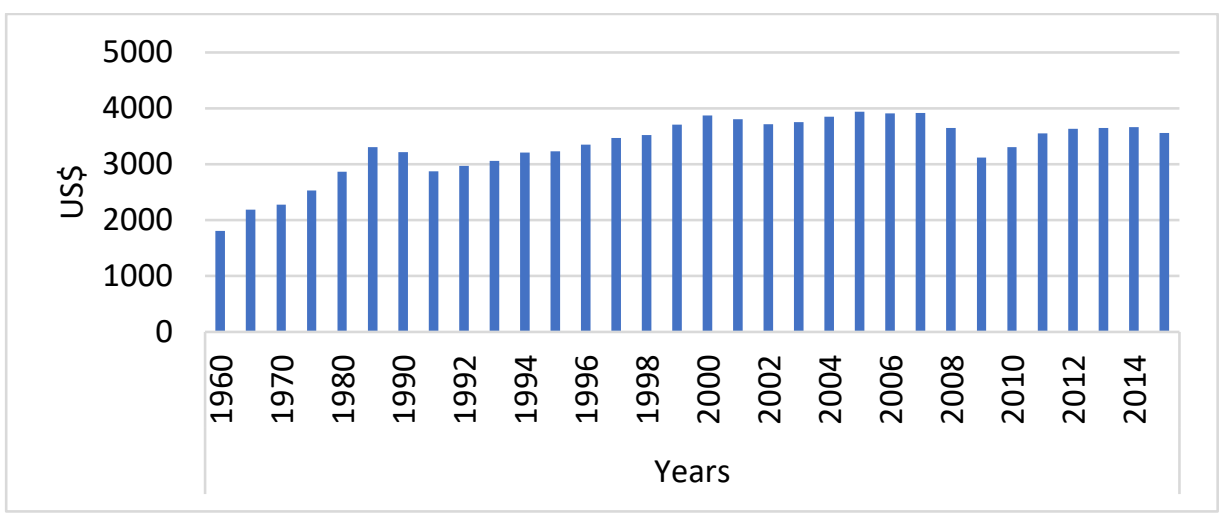

Fig. 2. Expenditures per Capita in 2014 US dollar (Source: Adapt [4])

Insecurity. The best indicator available for this disutility is the number of fatalities per million of inhabitants of seven modes of transportation [4], as shown in Fig. 3, and Tab. 2.

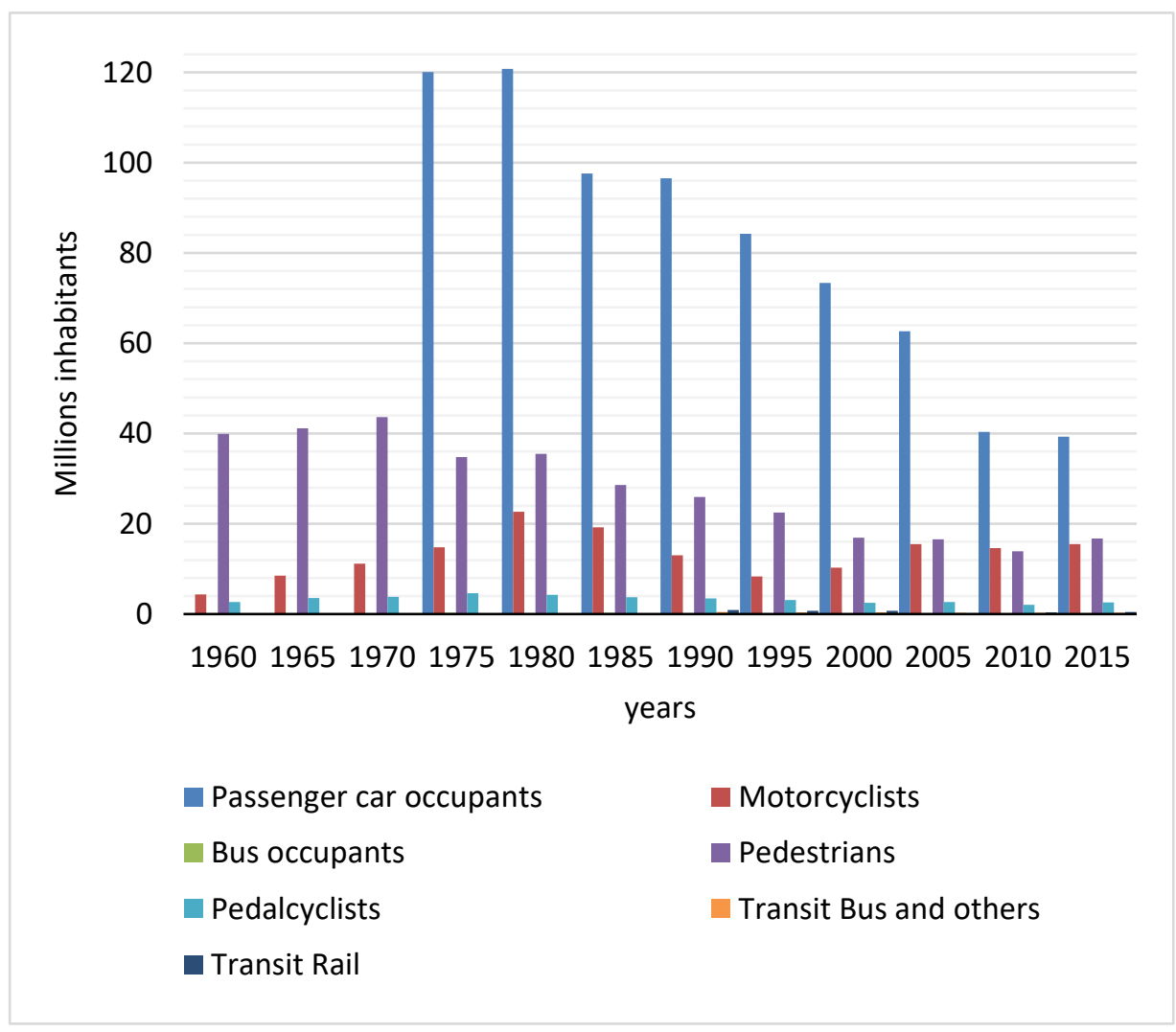

Fig. 3. Fatalities per Mode per Million of Inhabitants in the USA (Source: Adapt [4]) 
Table 2. Reduction of Insecurity Disutility by Mode

\begin{tabular}{|c|c|}
\hline Modes & Comments \\
\hline $\begin{array}{l}\text { Passenger car occu- } \\
\text { pants }\end{array}$ & $\begin{array}{l}\text { A decrease from } 120.0 \text { (1980) to } 39.0 \text { (2011), stability } \\
(2011 \text { to } 2014)(40.0)\end{array}$ \\
\hline Motorcyclists & $\begin{array}{l}\text { Worrying highs and lows. Increase from } 1960 \text { to } 1980 \\
(23.0) \text {, decrease }(1980-1997)(8.0) \text {, increase }(1997- \\
\text { 2008) (18.0), stability }(2008-2015)(15.0)\end{array}$ \\
\hline Bus occupants & Negligible values, ranging from 0.0 to 0.1 \\
\hline Pedestrians & $\begin{array}{l}\text { The highest value }(44.0) \text { was in } 1970 \text {, the lowest }(16.0) \text { in } \\
2004 \text {, a trend of stability since } 1997(<20.0)\end{array}$ \\
\hline Pedalcyclists & $\begin{array}{l}\text { The highest value (5.0) was in } 1975 \text {, a trend of stability } \\
\text { (2.0) in recent years }\end{array}$ \\
\hline Transit bus and others & Negligible values, ranging from zero to 0.5 \\
\hline Transit rail & $\begin{array}{l}\text { Negligible values, ranging from zero to } 0.9 \text {, increases in } \\
\text { the } 1990 \mathrm{~s} \text {, recent stability, maximum values }( \pm 0.5)\end{array}$ \\
\hline
\end{tabular}

Discomfort. Three indicators are gathered [4]. In any case, they are insufficient to measure this disutility completely. They are: (i) "Average Age of Automobiles in Operation in the USA" (8.4 years (1996) to 11.6 (2016)); (ii) "The Percentage in Relation of to the Total Extension of U.S. Roadway by Functions, with Fair, Poor and Very Poor Conditions Measured by International Roughness Index (IRI)" (improvement); and (iii) "Conditions of U.S. Bridges by Type of Problem and Functional System" (improvement).

Negative Impacts on Communities. The available data/information can be considered insufficient to measure this disutility [4]. There is only one indicator related to GGE $\left(\mathrm{CO}_{2}\right)$, from 1990 to 2009, (i) "U.S. Carbon Dioxide Emissions from Energy Use by Transportation Sector" (a slight increase of $\pm 5 \%$ ), and a set of others to local gases: (ii) "Highway Vehicles Estimated National Emissions of Carbon Monoxide, Nitrogen Oxides, Volatile Organic Compounds, Particulate Matter (PM-10), (PM-2.5) and Sulfur Dioxide" (decrease).

\section{Results and Discussions}

\subsection{Main Findings, Consistency of the Results and Speculations Regarding Causes Behind Disutilities Behavior}

It can be said that the National Transportation Statistics 2018 provide satisfactory elements to measure all disutilities for automobiles, except for Discomfort and Negative Impacts on Communities. Concerning the collective modes disutilities, the elements provided can be considered insufficient. The speculations by each disutility are shown in Tab. 3. 
Table 3. Speculations Regarding Causes Behind Disutilities Behavior

\begin{tabular}{|c|c|}
\hline Disutility & Comments \\
\hline Time & $\begin{array}{l}\text { People are spending more time using cars in the USA possibly due } \\
\text { to (i) the increase in the average displacement distances, and (ii) the } \\
\text { reduction in average travel speeds. The maintenance of automobile } \\
\text { lead (modal split), the increase in the number of vehicles per capita, } \\
\text { and the stability in vehicle ownership by household justify the } \\
\text { increase of } 15 \% \text { in the average displacement distances [13]. Conges- } \\
\text { tion consistently increased explains the reduction of average travel } \\
\text { speeds [10] }\end{array}$ \\
\hline Cost & $\begin{array}{l}\text { People are spending more money using cars in the USA possibly } \\
\text { because (i) they are spending more time, and (ii) the average } \\
\text { vehicles prices increased more than the real median household } \\
\text { income. Rising prices could mean increases of operating costs } \\
\text { (related to the increase of fuel prices) and more expenses of } \\
\text { maintenance, insurance, and funding ("Consumer Price Index" [14], } \\
\text { and "Real Median Household Income in the United States" [15]) }\end{array}$ \\
\hline Insecurity & $\begin{array}{l}\text { Insecurity has decreased for all modes, even though the USA fall of } \\
\text { numbers does not have the same magnitude as the other developed } \\
\text { countries [16] }\end{array}$ \\
\hline Discomfort & $\begin{array}{l}\text { Discomfort regarding automobiles may have decreased due to im- } \\
\text { provements in the road infrastructure, even considering that the av- } \\
\text { erage fleet age has grown }\end{array}$ \\
\hline Negative & The reduction of local gas emissions probably is related to the \\
\hline Impacts on & alignment of the car industry at increasingly lower emission factors \\
\hline Communities & imposed by the regulations [17] \\
\hline
\end{tabular}

\section{Conclusions and Outllook}

According to the analysis of the National Transportation Statistics 2018, people using cars in the USA are spending more Time and money (Cost) at least since the 1990s.

There is no data and information available concerning Time and Cost disutilities for collective modes. On the other hand, for all modes of transportation, Insecurity disutility has decreased. Regarding Discomfort, there is not enough data to establish a definite outcome, although this disutility seems to have decreased in automobiles, even they have gotten older, but mainly due to improvements in the infrastructure.

Finally, when it comes to Negative Impacts on Communities, this disutility can only be measured regarding local gases (revealing a significant decrease). The National Transportation Statistics 2018 shows some gaps, both by the lack of more detailed data for local gases concerning data for each mode of transportation and by the lack in the historical series interrupted in 2009 for GGE taken only for the transportation sector, which is delaying a conclusive judgment on this point.

Further studies are needed to confirm the main findings of this paper and to extend the knowledge of passenger transport disutilities in the USA. Nevertheless, it is hoped that the findings encourage the development, production, and dissemination of statis- 
tics on the disutilities of passenger transport, preferably measured in per capita costs for all transportation modes to improve the understanding of the problems and to expand public policies beneficial to all.

\section{References}

1. Raymundo, H. Minimizing Passenger Transport Disutilities: a methodology to measure quality and performance. (Doctoral Dissertation). Paulista University, Brazil (2018).

2. Weiner, E. Urban transportation planning in the United States: history, policy, and practice. 5th ed. Springer, USA (2016).

3. Bureau of Transportation Statistics. Transportation Economic Trends 2018. https://www.bts.gov/sites/bts.dot.gov/files/u796/TET\%202018.pdf.

4. _ _ National Transportation 2018. https://www.bts.gov/sites/bts.dot.gov/files/docs/browse-statistical-products-anddata/national-transportation-statistics/223001/ntsentire2018q4.pdf

5. Raymundo, H.; Reis, J. G. M. Measures for Passenger Transport Perfo.rmance Evaluation in Urban Areas. Journal of Urban Planning and Development. Vol. 144, Issue 3 (2018).

6. ___ Urban Mobility at Risk in Brazil: Passenger Transport Disutilities increase from 2003 to 2014. In: International Conference on Network Enterprise \& Logistic Management. Paulista University, Brazil (2018).

7. Raymundo, H.; Reis, J. G. M. Measuring passenger transport quality by disutilities. In: 6th International Conference in Information, Systems, Logistics and Supply Chain Conference, Kedge University, France (2016).

8. ___. Passenger Transport Drawbacks: An Analysis of Its "Disutilities" Applying the AHP Approach in a Case Study in Tokyo, Japan. In: IFIP International Conference on Advances in Production Management Systems. Springer, Germany (2017).

9. Texas A\&M Transportation Institute; INRIX, Inc. 2015 Urban Mobility Scorecard. https://static.tti.tamu.edu/tti.tamu.edu/documents/mobility-scorecard-2015.pdf/.

10. Texas A\&M Transportation Institute. Technical Memorandum - Analysis Procedures and Mobility Performance Measures - 100 Most Congested Texas Road Sections. https://static.tti.tamu.edu/tti.tamu.edu/documents/TTI-2017-8.pdf.

11. US Inflation Calculator. https://www.usinflationcalculator.com/, last accessed 2019/03/19.

12. United States Census Bureau. Population Estimates from 1900 to 1999: Historical National, 2000 - 2010: Intercensal Estimates, and 2010 - 2018: Monthly Population Estimates for the United States. https://www.census.gov/.

13. The Transport Politic. https://www.thetransportpolitic.com/databook/.

14. Federal Reserve Bank of St. Louis/Economic Research. Consumer Price Index for All Urban Consumers: New vehicles, https://fred.stlouisfed.org/series/CUUR0000SETA01.

15. _ . Real Median Household Income in the United States [MEHOINUSA672N], https://fred.stlouisfed.org/series/MEHOINUSA672N.

16. Evans, L. Twenty Thousand More Americans Killed Annually Because US Traffic-Safety Policy Rejects Science. American Journal of Public Health, 104(8), 1349 (2014).

17. U.S. Environmental Protection Agency. 2017 and Later Model Year Light-Duty Vehicle Greenhouse Gas Emissions and Corporate Average Fuel Economy Standards. https://influencemap.org/site/data/000/024/EPA_Comments_on_Light_CAFE_Standards_ 2017.pdf. 